\title{
A DURAÇÃo RAZOÁVEL DO PROCESSO NO DIREITO BRASILEIRO E O NOVO CÓDIGO DE PROCESSO CIVIL: AVANÇOS E RECUOS ${ }^{1}$
}

\section{THE REASONABLE TIME OF THE PROCESS IN THE BRAZILIAN LAW AND THE NEW CIVIL PROCEDURE CODE: PROGRESS AND SETBACKS}

Elaine Harzheim Macedo Doutora e Mestre em Direito, Especialista em direito processual civil, Professora na Graduação e no Programa de Pós-Graduação em Direito junto à PUCRS. Desembargadora aposentada do Tribunal de Justiça do Rio Grande do Sul. Ex-Presidente do Tribunal Regional Eleitoral do Rio Grande do Sul. Membro do Instituto dos Advogados do Rio Grande do Sul. Advogada. Porto Alegre/RS. elaine@fhm.adv.br.

Volgane Oliveira Carvalho Mestre em Direito pela Pontifícia Universidade Católica do Rio Grande do Sul. Professor do Curso de Direito do Instituto Camillo Filho. Analista Judiciário do Tribunal Regional Eleitoral do Maranhão.volganeoc@gmail.com.

RESUMO: Este trabalho tem por objetivo analisar a natureza jurídica assumida pelo instituto da duração razoável do processo no direito brasileiro. Inicialmente observa-se que a busca por um processo célere não é recente e que a ideia adentrou no Brasil antes da promulgação da Constituição de 1988. Posteriormente, são esmiuçadas as três principais classificações de caráter constitucional que apontam o instituto como regra, princípio e regra-princípio. Posteriormente, o instituto é analisado sob a perspectiva infraconstitucional, notadamente, sob a ótica do novo Código de Processo Civil, com a análise minudente dos contributos do novel diploma processual para o incremento da

\footnotetext{
${ }^{1}$ Artigo recebido em 18/04/15 e aprovado em 11/06/2015.
} 
Revista Eletrônica de Direito Processual - REDP. Volume 15. Janeiro a Junho de 2015 Periódico Semestral da Pós-Graduação Stricto Sensu em Direito Processual da UERJ. Patrono: José Carlos Barbosa Moreira. www.redp.com.br ISSN 1982-7636 PP 74-106

celeridade do processo. De tudo, emerge a necessidade inafastável de fixação de balizas conceituais claras que definam a duração razoável do processo propiciando a realização de sua efetividade no cotidiano dos jurisdicionados.

PALAVRAS-CHAVE: Duração razoável do processo. Princípios constitucionais. Novo Código de Processo Civil.

ABSTRACT: This paper aims to examine the legal nature assumed by the reasonable duration of the institute process in Brazilian law. It is observed initially that the search for a speedy process is not new and that the idea entered in Brazil before the enactment of the Constitution of 1988. Subsequently the three main constitutional classifications that point the institute as rule, principle and rule-principle are sorted out. Later, the institute is analyzed under the infra perspective, especially from the perspective of the new Civil Procedure Code, with the close analysis of the contributions of the new procedural law to increase the speed of the process. Above all, the unremovable need for fixing clear conceptual beacons that define the reasonable duration of the process enabling the realization of its effectiveness in the daily lives of jurisdictional emerges.

KEYWORDS: Reasonable duration of the process. Constitutional principles. New Civil Procedure Code.

\section{INTRODUÇÃO}

Desde priscas eras a vida humana em sociedade exigiu o estabelecimento de limites para a convivência mimetizados em inúmeras normas orais e escrita. Estas estruturas tiveram de ser aperfeiçoadas com o passar do tempo, dada a existência de uma realidade envolta em novas complexidades, mas algumas estruturas e anseios permanecem quase inalterados.

A função de resolução de conflitos interpessoais prossegue sendo um monopólio estatal, salvo raras exceções. Cabe ao Estado-juiz a aplicação da lei no caso concreto com toda a lisura e imparcialidade possíveis, representando significativa atividade 
Revista Eletrônica de Direito Processual - REDP. Volume 15. Janeiro a Junho de 2015 Periódico Semestral da Pós-Graduação Stricto Sensu em Direito Processual da UERJ. Patrono: José Carlos Barbosa Moreira. www.redp.com.br ISSN 1982-7636 PP 74-106

construtiva da ordem jurídica enquanto concretude, enquanto poder criativo de compor a solução específica daquele caso submetido a julgamento.

De outra banda, o jurisdicionado hodierno continua com os mesmos desejos daqueles do medievo: realização plena e rápida da justiça, quiçá mais premido ainda pela exigência da pós-modernidade, onde o tempo ganhou dimensão diversa, sobrepondo-se aos anos, os meses; aos meses, os dias; aos dias, a hora; à hora os minutos ou os segundos. De lembrar a lição de Marco Félix Jobim², ao constatar que à noção de tempo sobrepõe-se a (nova) noção de perda do tempo, sendo esta um produto das últimas décadas, onde o tempo não só passou a ser uma raridade, como ainda um bem comerciável.

$\mathrm{Na}$ realidade brasileira merecem destaque entre os problemas enfrentados pelo Poder Judiciário as questões relacionadas à rápida resolução das lides, especialmente quando se tem em mente o aumento exponencial da qualidade dos julgados e a consequente redução do erro judiciário, metas irrenunciáveis num Estado democrático de Direito.

Para a solução do problema a legislação processual tem buscado variadas soluções, investindo ora em técnicas procedimentais, a exemplo da sumarização do procedimento, ora na documentação dos atos processuais, como é o caso do e-processo, ora na facilitação da comunicação dos atos processuais, utilizando-se de vias alternativas, como foi o caso, hoje um pouco mais remoto, mas ainda em plena vigência, da citação por carta AR. Entre essas iniciativas, uma das importantes inovações surgidas foi a positivação, em sede de garantia constitucional, da duração razoável do processo. Contudo, a definição da natureza jurídica do instituto ainda é uma questão à espera de uma resposta.

Em que pese seu caráter nitidamente constitucional, a duração razoável do processo possui, também, repercussão na esfera infraconstitucional. Nesse sentido, a promulgação de um novo Código de Processo Civil (CPC) é uma oportunidade ímpar para reavivar e aprofundar tal debate. Nesse sentido, é imprescindível a análise do contributo efetivo que o novel diploma legislativo apresenta para a efetivação do princípio constitucional.

\footnotetext{
2 JOBIM, Marco Féliz. O Direito à duração razoável do processo: responsabilidade civil do Estado em decorrência da intempestividade processual. 2. ed. rev. e ampl. Porto Alegre: Livraria do Advogado, 2012. p. 24-26.
} 
Revista Eletrônica de Direito Processual - REDP. Volume 15. Janeiro a Junho de 2015 Periódico Semestral da Pós-Graduação Stricto Sensu em Direito Processual da UERJ. Patrono: José Carlos Barbosa Moreira. www.redp.com.br ISSN 1982-7636 PP 74-106

Assim, a análise da duração razoável do processo há que se realizar por via dúplice e hierarquizada, ora observando o panorama constitucional, ora reconhecendo as especificidades das diretrizes estabelecidas pelo diploma processual civil máximo. Apenas através da conjugação dessas duas vias será possível a concretização do princípio constitucional.

O estabelecimento de balizas definidoras é essencial para o aperfeiçoamento das ideias relacionadas ao tempo de vida do processo permitindo que sejam fixadas regras de aplicabilidade e interpretação sobre o tema, e indiscutivelmente permitindo que se alcance a almejada eficácia social plena.

Uma pesquisa estruturada acerca da duração razoável do processo deve analisar a questão sob todas as perspectivas reconhecendo as múltiplas facetas que possui: norma constitucional, princípio, regra-princípio e norma infraconstitucional. Isto é o que se pretende realizar doravante.

\section{ESBOÇO HISTÓRICO}

No ambiente jurídico internacional as propostas relacionadas com a celeridade processual são tão antigas quanto a luta por um rol de direitos e garantias fundamentais. Conforme Alba Azevedo e Maria dos Remédios Fontes ${ }^{3}$ o modelo de um estatuto normativo de direitos e garantias, inclusive com previsão para a questão temporal, surgiu na Magna Carta, em 1215, e depois foi replicado pela Declaração Americana dos Direitos e Deveres do Homem, pela Convenção Europeia dos Direitos Fundamentais dos Homens e das Liberdades Fundamentais, pelas Constituições da Espanha e da Itália e pelo Pacto de San Jose da Costa Rica.

No Brasil, assim como nos demais ordenamentos, a defesa da celeridade processual, embora, existam posicionamentos claramente contrários a isto ${ }^{4}$ (AZEVEDO; FONTES, 2009), não é recente, sendo anterior à Emenda Constitucional

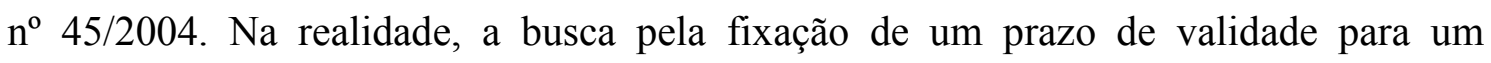
processo não representa um pensamento inovador vez que decorre do desejo de uma

\footnotetext{
3 AZEVEDO, Alba Paulo de; SILVA, Maria dos Remédios Fontes. O direito fundamental à duração razoável do processo: abordagem sob uma perspectiva garantista do processo penal. In: Encontro Nacional do CONPEDI, XVIII., 2009, Maringá. Anais do XVIII Encontro Nacional do CONPEDI. [s. l.]: CONPEDI, 2009. p. 4.039-4.059.

${ }^{4}$ AZEVEDO, Alba Paulo de; SILVA, Maria dos Remédios Fontes. Op. cit..
} 
Revista Eletrônica de Direito Processual - REDP. Volume 15. Janeiro a Junho de 2015 Periódico Semestral da Pós-Graduação Stricto Sensu em Direito Processual da UERJ. Patrono: José Carlos Barbosa Moreira. www.redp.com.br ISSN 1982-7636 PP 74-106 prestação jurisdicional de qualidade. Como recordam Nestor Santiago e Ana Caroline Duarte $^{5}$, também, encontram respaldo no próprio acesso universal à Justiça:

Dessa forma, o direito de acesso ao Poder Judiciário, como uma das formas de consecução do mencionado princípio, também engloba o direito que todo jurisdicionado tem de ver a ação julgada em um prazo razoável, o que representa, em outras palavras, o direito à tutela jurisdicional tempestiva e adequada, sob pena de se negar a realização da justiça no caso concreto.

Assim, a "novidade" inserida pelo constituinte é a especificação de um ideário que já constava da Constituição desde a sua redação anterior, mas que ainda não havia alcançado a plenitude de sua eficácia social, gravitando entre os escaninhos legislativos, o pensamento dos doutrinadores e as decisões de raros juízos ${ }^{6}$. Coaduna com esta opinião o fato de a duração razoável do processo constar, mesmo que de forma tímida, do Tratado de San Jose da Costa Rica do qual o Brasil é signatário e que vigora desde meados dos anos 1990. Como explicar então a completa ausência de medidas de incentivo à celeridade processual neste período?

Até a reforma constitucional perpetrada em 2004 o Supremo Tribunal Federal, em dissonância com a grande maioria da doutrina, apontava que as normas oriundas de tratados internacionais adentravam no ordenamento nacional com caráter de lei infraconstitucional. Desta maneira, a defesa da duração razoável do processo era apenas uma expectativa que precisava ser materializada em uma lei ordinária.

A assunção da Emenda Constitucional n ${ }^{\circ}$ 45/2004 resolveu os dois problemas de uma vez, insculpiu no rol de direitos o instituto e estabeleceu expressamente que as normas decorrentes de documentos internacionais dos quais o Brasil fosse signatário, se referentes a direitos humanos, deveriam receber um tratamento diferenciado, não podendo ser compreendidas como simples normas infraconstitucionais.

Diante disso, pode-se dizer que a reforma constitucional de 2004 não teve o condão de criar no direito brasileiro um instituo novel e surpreendente, mas teve o forte

\footnotetext{
5 SANTIAGO, Nestor Eduardo Araruna; DUARTE, Ana Caroline Pinho. Um conceito de duração razoável do processo penal. Revista NEJ-Eletrônica, v. 15, n. 2, maio/ago. 2010. p. 244.

${ }^{6}$ SCHMITT, Cristiano Heineck. Direito à razoável duração do processo no Brasil: origens, inobservância e tentativas de concretização. Revista da Faculdade de Direito da UFG, v. 34, n. 1, jan./jun. 2010. p. 4063.
} 
Revista Eletrônica de Direito Processual - REDP. Volume 15. Janeiro a Junho de 2015 Periódico Semestral da Pós-Graduação Stricto Sensu em Direito Processual da UERJ. Patrono: José Carlos Barbosa Moreira. www.redp.com.br ISSN 1982-7636 PP 74-106

mérito na realização da árdua missão de resgatá-lo das sombras e colocá-lo no centro da ribalta jurídica.

\section{CONCEITO DE DURAÇÃO RAZOÁVEL DO PROCESSO}

Antes de passar ao estudo minudente da natureza jurídica da duração razoável do processo, é importante que seja fixado um conceito para tal instituto. Esta tarefa não é das mais simples, vez que muitos doutrinadores já dedicaram longos articulados a esta figura, mas poucos se arriscaram a ofertar uma definição direta.

Realizando uma interpretação simplória é possível compreender que a duração razoável do processo é a busca pelo estabelecimento de balizas regulatórias do processo que tenham por objetivo impedir o abuso de direito do Estado ou das partes produzindo um quadro de instabilidade jurídica e agressão a direitos fundamentais. Assim:

[...] o princípio da duração razoável do processo é aquele segundo o qual o procedimento satisfaz o tempo devido do modelo constitucional de processo, assim entendido o espaço temporal necessário para que seja garantido aos interessados o exercício do contraditório e da ampla defesa (argumentação) perante um magistrado imparcial e comprometido com decisões devidamente fundamentadas. Em outras palavras, a duração do processo não deve ser avaliada com base exclusivamente no tempo cronológico, mas sim no tempo devido para o desenvolvimento de um processo compatível com a moldura estabelecida constitucionalmente. ${ }^{7}$

É de se observar que o conceito acima acresce outros elementos essenciais à definição: lapso temporal e a necessidade de solução da lide. Assim, a duração razoável do processo não busca a realização de um processo açodado e sujeito ao erro, ao inverso, é a busca da perfeita conjugação da celeridade com a qualidade o que

\footnotetext{
${ }^{7}$ COUTINHO, Carlos Marden Cabral. Reformas processuais e duração razoável do processo: uma análise à luz do conceito de tempo kairológico. In: Encontro Nacional do CONPEDI, XXI, 2012, Niterói. Anais do XXI Encontro Nacional do CONPEDI. Florianópolis: FUNJAB, 2012. p. 348.
} 
Revista Eletrônica de Direito Processual - REDP. Volume 15. Janeiro a Junho de 2015 Periódico Semestral da Pós-Graduação Stricto Sensu em Direito Processual da UERJ. Patrono: José Carlos Barbosa Moreira. www.redp.com.br ISSN 1982-7636 PP 74-106

redundará, invariavelmente, no respeito à dignidade das partes e na concretização do direito.

E enquadrando como ilícito processual a ofensa ao tempo razoável do processo, Marco Félix $\mathrm{Jobim}^{8}$ defende:

A jurisdição deve ser prestada ao cidadão dentro de um prazo razoável, razão pela qual deve-se estudar as possibilidades de penalização daqueles que deixam o processo no descaminho da tempestividade, tanto direta como indiretamente, permitindo seu alargamento temporal indefinidamente.

Esse contexto mostra que a duração razoável do processo entrou no ordenamento jurídico brasileiro como um valor maior, a ser, portanto, bem compreendido e aplicado pelos operadores do Direito, passando a constituir um autêntico vetor do processo.

A jurisprudência brasileira patina na produção de julgados que aliviem a necessidade de definição do conceito de duração razoável do processo, contudo, já emergem decisões que reconhecem tal direito fundamental e determinam o pagamento de indenizações por seu desrespeito. Nesse sentido:

Em homenagem ao princípio da duração razoável do processo, insculpido no art. $5^{\circ}$, inciso LXXVIII, da Carta Magna, havendo demora injustificada na prestação jurisdicional, causando prejuízo ao jurisdicionado, deve o Estado indenizar o dano eventualmente sofrido pela parte ${ }^{9}$.

Tal julgado é, indubitavelmente, paradigmático, contudo, ainda não contribui efetivamente para a formação de um conceito firme que estabeleça o tempo de vida necessário para um processo.

\footnotetext{
${ }^{8}$ JOBIM, Marco Féliz. Op. cit. p. 70.

9 ACRE. TRIBUNAL DE JUSTIÇA. Constitucional, Civil e Processual Civil. Indenização por danos morais e patrimoniais. Ação de justificação de reconhecimento de união estável. Demora na prestação jurisdicional. Desídia. Prejuízo da parte autora. Dano configurado. Indenização devida. Apelação Cível no 9. Antônia Norlene Alves X Estado do Acre. Órgão Julgador: Câmara Cível. Relator: Miracele Lopes. Data da publicação: 29/10/2009.
} 
Revista Eletrônica de Direito Processual - REDP. Volume 15. Janeiro a Junho de 2015 Periódico Semestral da Pós-Graduação Stricto Sensu em Direito Processual da UERJ. Patrono: José Carlos Barbosa Moreira. www.redp.com.br ISSN 1982-7636 PP 74-106

Enquanto o Brasil recalcitra na criação de um conceito positivo para a duração razoável do processo o Direito Comunitário Europeu há alguns anos procura estabelecer balizas norteadoras para a construção de tal definição. O Tribunal Europeu dos Direitos Humanos julgamento do Caso Martins Castro e Alves Correia de Castro contra Portugal $^{10}$, refere a existência de tais bases teóricas:

O Tribunal lembra que a razoabilidade da duração de um processo aprecia-se de acordo com as circunstâncias da causa e tendo em vista os critérios consagrados pela sua jurisprudência, em particular a complexidade da causa, o comportamento do requerente e o das autoridades competentes bem como o interesse da causa (enjeu du litige) para os interessados $[\ldots]^{11}$.

A complexidade da causa pode ser medida por inúmeros mecanismos, tais quais: o número de pessoas envolvidas no processo, o nível de complexidade das questões debatidas na lide, o montante de fatos a serem a analisados, bem como a necessidade de realização de diligências, perícias ou outros procedimentos complexos.

A complexidade das questões debatidas, por si só, não pode ser apontada como resposta para a demora do julgamento, especialmente em se tratando de complexidade de direito, mas causas faticamente complexas denotam uma instrução mais cuidadosa a exigir a produção de sentenças mais estruturadas e bem embasadas, o que implica custo temporal.

O comportamento das partes também é essencial para designar a velocidade da marcha processual. A boa-fé das partes e a abstenção de atos meramente protelatórios ou desnecessários à resolução da lide são importantes para a produção de uma decisão célere. O comportamento das autoridades, por seu turno, diz respeito à atuação do magistrado como condutor do processo e a seu papel na modulação do andamento do processo. A necessidade de uma efetiva e tempestiva prestação jurisdicional não pode ser compreendida como aceleração do processo.

\footnotetext{
${ }^{10}$ No mesmo sentido a decisão do Caso Frydlender contra França.

${ }^{11}$ EUROPA. Tribunal Europeu dos Direitos do Homem. Caso Martins Castro e Alves Correia de Castro contra Portugal. $\mathrm{n}^{\mathrm{o}}$ Queixa $\mathrm{n}^{\mathrm{o}}$ 33729/06. Julgado em 10 de jun de 2008. Disponível em: $<$ http://www.gddc.pt/direitos-humanos/portugal-

$\mathrm{dh} /$ acordaos/traducoes/Acord\%E3o\%20martins\%20de\%20castro\%20tradu\%E7\%E3o\%20portugu\%EAs \%20-\%20vers\%E3o\%20final1.pdf>. Acesso em: 08 jun. 2015.
} 
Revista Eletrônica de Direito Processual - REDP. Volume 15. Janeiro a Junho de 2015 Periódico Semestral da Pós-Graduação Stricto Sensu em Direito Processual da UERJ. Patrono: José Carlos Barbosa Moreira. www.redp.com.br ISSN 1982-7636 PP 74-106

Por fim, o interesse da causa refere-se às necessidades das partes de receberem rapidamente a prestação jurisdicional. Tal anseio é mais gravoso entre os hipossuficientes como idosos, portadores de doenças graves e crianças, v. g., por conta disso eles acabam recebendo o benefício de um andamento processual mais veloz.

\section{DURAÇÃO RAZOÁVEL DO PROCESSO COMO NORMA CONSTITUCIONAL}

As primeiras teorias definidoras da natureza jurídica da duração razoável do processo são aquelas que a enquadram como norma constitucional. Essa percepção é correta em seu intento, contudo, carrega um problema referente ao período anterior a 2004. Antes da reforma constitucional não havia nenhuma norma que declarasse expressa e explicitamente a existência do instituto no direito brasileiro até mesmo porque o Tratado de San Jose da Costa Rica tratava da questão de modo incidental exigindo uma interpretação ampliativa do operador do Direito. Assim, a necessária completude surge apenas com a edição da Emenda Constitucional nº 45/2004.

Nesse sentido, o caráter constitucional do instituto estaria umbilicalmente ligado com a sua inserção na Carta Política. Esta constatação enfraquece a defesa da tese de classificação como mera regra constitucional.

\subsection{EFICÁCIA DAS NORMAS CONSTITUCIONAIS}

Considerando que a duração razoável do processo seja uma regra constitucional, torna-se indiscutível a necessidade de adentrar no tema da eficácia destas normas e de sua aplicabilidade. No Brasil desde a Constituição Republicana de 1891 até a década de 1960 adotou-se a teoria estadunidense que divide as normas em dois grandes filões: autoaplicáveis (self-executing) e não autoaplicáveis (not self-executing). Segundo Rafael Maffini ${ }^{12}$ :

No direito brasileiro aponta-se corretamente Ruy Barbosa como precursor do enfretamento do tema da eficácia das normas

\footnotetext{
${ }^{12}$ MAFFINI, Rafael Da Cá. Emenda Constitucional no 45/04 e o conceito de atividade jurídica como requisito de ingresso nas carreiras da magistratura e do Ministério Público. Salvador, Revista Eletrônica sobre a reforma do Estado, n. 15, set./nov. 2008. p. 4.
} 
Revista Eletrônica de Direito Processual - REDP. Volume 15. Janeiro a Junho de 2015 Periódico Semestral da Pós-Graduação Stricto Sensu em Direito Processual da UERJ. Patrono: José Carlos Barbosa Moreira. www.redp.com.br ISSN 1982-7636 PP 74-106

constitucionais. Para este inigualável jurista, seguindo nitidamente influências norte-americanas, as normas constitucionais seriam dividas em duas espécies. De um lado, haveria as normas auto-executáveis (ou auto-aplicáveis) [...]. de outro, as normas não-auto-executáveis (ou não-auto-aplicáveis) $[\ldots]$.

As normas autoaplicáveis estariam aptas a gerar todos os seus efeitos independentemente de qualquer atuação ulterior do legislador infraconstitucional, são, pois, completas no que determinam. As normas não autoaplicáveis, por sua vez, necessitam de atuação positiva do legislador para tornar efetivos os seus preceitos, são ideias que carecem de concretização.

Essa classificação tradicional, entretanto, esta sujeita a muitas críticas. Inicialmente, há que se inferir que o termo autoaplicabilidade, soa como imodificável, quando, na realidade, nada obsta que ocorra uma complementação do texto constitucional por outras normas posteriores de igual talame. De outra banda, o termo não autoaplicáveis transmite a errônea impressão de que não possui qualquer tipo de eficácia, o que não é verdade, uma vez que, como normas constitucionais que são, possuem em seu âmago, necessariamente, algum poder cogente.

O conjunto de críticas ganhou força por conta do caráter ultrapassado da teoria, visto que remontava ao final do século XIX e dizia respeito a uma realidade jurídica completamente diversa. Assim, nos anos 1960, alguns estudiosos propuseram-se a apresentar teorias alternativas para classificar a eficácia das normas constitucionais no direito pátrio. Desde então, emergiram quase uma dezena de classificações, destes são repristinados com mais frequência os trabalhos de José Afonso da Silva e Maria Helena Diniz.

\subsubsection{Classificação de José Afonso da Silva}

José Afonso da Silva propõe que as normas constitucionais, segundo sua eficácia, sejam classificadas em três grandes categorias, quais sejam: normas de eficácia plena, normas de eficácia contida e normas de eficácia limitada ou reduzida. 
Revista Eletrônica de Direito Processual - REDP. Volume 15. Janeiro a Junho de 2015 Periódico Semestral da Pós-Graduação Stricto Sensu em Direito Processual da UERJ. Patrono: José Carlos Barbosa Moreira. www.redp.com.br ISSN 1982-7636 PP 74-106

As normas de eficácia plena possuem um caráter de completude e por isso, não precisam receber qualquer espécie de complementação pelo legislador ordinário para que entrem em vigor e gozem de completa eficácia.

As normas de eficácia contida possuem uma aplicabilidade direta e imediata, contudo, não integral visto que podem ser objeto de modificação (de cunho restritivo) por parte do poder público, mas independem disso para alcançar a plena vigência.

Segundo José Afonso da Silva ${ }^{13}$ as normas de eficácia limitada:

São todas as que não produzem, com a simples entrada em vigor, todos os seus efeitos essenciais, porque o legislador constituinte, por qualquer motivo não estabeleceu, sobre a matéria, uma normatividade para isso bastante, deixando essa tarefa ao legislador ordinário ou a outro órgão do Estado.

Dessa forma, as normas de eficácia limitada ou reduzida não receberam o poder do legislador constituinte para alcançar pleno desenvolvimento; necessitam, imperiosamente, de complementação pelo legislador ordinário para que possam alcançar seu ápice de validade.

\subsubsection{Classificação de Maria Helena Diniz}

Maria Helena Diniz apresenta uma das mais recentes teorias acerca da eficácia das normas constitucionais. Segundo seu pensamento existem as seguintes categorias: normas com eficácia absoluta, normas com eficácia plena, normas com eficácia relativa restringível e normas com eficácia relativa complementáveis ou dependentes de complementação. Divide, pois, as eficácias em quatro grupos distintos.

As normas com eficácia absoluta, ou supereficazes, seriam aquelas que são insuscetíveis de alteração até mesmo por Emenda Constitucional, são a base do ordenamento jurídico pátrio, as clausulas pétreas que são imodificáveis, intangíveis. Nessa categoria, se incluiriam, portanto, os direitos e garantias fundamentais.

\footnotetext{
${ }^{13}$ SILVA, José Afonso da. Aplicabilidade das normas constitucionais. 5. ed. São Paulo: Malheiros, 2001. p. $82-83$.
} 
Revista Eletrônica de Direito Processual - REDP. Volume 15. Janeiro a Junho de 2015 Periódico Semestral da Pós-Graduação Stricto Sensu em Direito Processual da UERJ. Patrono: José Carlos Barbosa Moreira. www.redp.com.br ISSN 1982-7636 PP 74-106

As normas com eficácia plena são aquelas que independem de lei infraconstitucional para que possam atingir seu ápice de eficácia. As normas com eficácia relativa restringível são aplicáveis no cotidiano, contudo, poderão ter sua ação minimizada por ulterior atuação do Poder Público. Assevera Maria Helena Diniz ${ }^{14}$ :

Não receberam, portanto, do constituinte normatividade suficiente para a sua aplicação imediata, porque ele deixou ao Legislativo a tarefa de regulamentar a matéria, logo, por esta razão, não poderão produzir todos os seus efeitos de imediato, porém têm aplicabilidade mediata, já que incidirão totalmente sobre os interesses tutelados, após o regramento infraconstitucional.

Assim, as normas com eficácia relativa complementável, também chamadas dependentes de complementação legislativa, ou de aplicação apenas mediata, são aquelas que precisam de intervenção posterior do legislador ordinário para que possam surtir os efeitos desejados pelo constituinte.

\subsubsection{A posição de Ingo Wolfgang Sarlet}

Ingo W. Sarlet ${ }^{15}$, no intuito de compor as classificações doutrinárias quanto à eficácia das normas constitucionais, concluindo que a rigor não se excluem, leciona:

[... Em face do exposto, pode falar-se em normas constitucionais de alta densidade normativa, que, dotadas de suficiente normatividade, se encontram aptas a, diretamente e sem a intervenção do legislador ordinário, gerar os seus efeitos essenciais (independentemente de uma ulterior restringibilidade), bem como em normas constitucionais de baixa densidade normativa, que não possuem normatividade

\footnotetext{
${ }^{14}$ DINIZ, Maria Helena. Norma constitucional e seus efeitos. 4. ed. atual. São Paulo: Saraiva, 1998. p. 114.

15 SARLET, Ingo Wolfgang. A eficácia dos direitos fundamentais. 7. ed. rev., atual. e ampl., Porto Alegre: Livraria do Advogado, 2007. p. 264.
} 
Revista Eletrônica de Direito Processual - REDP. Volume 15. Janeiro a Junho de 2015 Periódico Semestral da Pós-Graduação Stricto Sensu em Direito Processual da UERJ. Patrono: José Carlos Barbosa Moreira. www.redp.com.br ISSN 1982-7636 PP 74-106

suficiente para - de forma direta e sem uma interpositio legislatoris - gerar seus efeitos principais, ressaltando-se que, em virtude de uma normatividade mínima (presente em todas as normas constitucionais), sempre apresentam certo grau de eficácia jurídica.

Deposita, pois, o constitucionalista gaúcho no critério da densidade normativa, ainda que não em caráter exclusivo, o ângulo classificatório, tendo como foco as normas constitucionais em geral.

\subsection{EFICÁCIA DAS NORMAS CONSTITUCIONAIS DEFINIDORAS DE DIREITOS FUNDAMENTAIS}

É pacífico entre doutrinadores e julgadores que as normas definidoras dos direitos e garantias fundamentais são autoaplicáveis, não estando presas a procedimentos legislativos posteriores para a aquisição de sua efetividade definitiva e sua aplicação material. $\mathrm{O}$ comando é da própria Constituição ${ }^{16}$.

Ademais, os direitos e garantias fundamentais foram inscritos pelo legislador constituinte entre o rol das cláusulas pétreas, que não podem ser alteradas de modo supressivo pelo legislador ordinário. Dessa maneira, as normas definidoras dos direitos fundamentais no ordenamento jurídico brasileiro estão, indubitavelmente, no ápice da eficácia.

Inexistem dúvidas de que a natureza dos ideais da duração razoável do processo conjugada com a sua localização topográfica faz com que seja classificada como um direito fundamental e desta maneira, possua eficácia plena imediata deste a publicação da Emenda Constitucional no 45/2004.

Por via de consequência, não há a necessidade de elaboração de uma norma complementar para disciplinar o tema para que algum cidadão seja beneficiado com a diretriz constitucional. Este raciocínio justifica os defensores da tese de que o instituto da duração razoável do processo é uma regra constitucional. A preocupação que aflige os aplicadores do Direito refere-se à busca da plena efetividade da norma. Dessa forma:

\footnotetext{
${ }^{16}$ Art. $5^{\circ}[\ldots] \S 1^{\circ}$ As normas definidoras dos direitos e garantias fundamentais têm aplicação imediata.
} 
Revista Eletrônica de Direito Processual - REDP. Volume 15. Janeiro a Junho de 2015 Periódico Semestral da Pós-Graduação Stricto Sensu em Direito Processual da UERJ. Patrono: José Carlos Barbosa Moreira. www.redp.com.br ISSN 1982-7636 PP 74-106

A efetividade significa, portanto, a realização do Direito, o desempenho concreto de sua função social. Ela representa a materialização, no mundo dos fatos, dos preceitos legais e simboliza a aproximação, tão íntima quanto possível, entre o dever-ser normativo e o ser da realidade social. ${ }^{17}$

Assim, a luta engendrada na atualidade diz respeito à criação de fórmulas que permitam a adequada realização da eficácia das normas constitucionais em sua plenitude. Neste diapasão, no caso específico da duração razoável do processo o caminho para a real aplicação do instituto parece passar pela edição de uma lei que discipline a matéria.

Vem de Marco Félix Jobim ${ }^{18}$ a lição de que o próprio texto constitucional já permite que a legislação infraconstitucional estabeleça os critérios para a melhor operacionalização do comando, inclusive com vistas a sancionar o maior responsável por sua infração, o Estado, a saber:

Contudo, o próprio inciso LVXXIII responde ao questionamento, ao ser lida a sua segunda parte, ao dizer que também são direitos dos jurisdicionados "[...] os meios que garantam a celeridade de sua tramitação", ou seja, podendo esses meios ser alvo de legislação infraconstitucional deixa aberta uma regulamentação disciplinando a matéria.

Dizendo de outra forma, o grau de densidade normativa, sem discussão quanto à sua auto-aplicabilidade, autoriza espaço para intervenção do Poder Legislativo.

\section{DURAÇÃO RAZOÁVEL DO PROCESSO COMO PRINCÍPIO}

O Direito passou por algumas fases marcantes em sua evolução como ciência, especialmente a partir do século XVIII. Inicialmente, assumiu posição de destaque o

17 BARROSO, Luis Roberto. O direito constitucional e a efetividade de suas normas: limites e possibilidades da Constituição brasileira. 6.ed. atual. Rio de Janeiro: Renovar, 2002. p. 85.

${ }^{18}$ JOBIM, Marco Félix. Op. cit. p. 100. 
Revista Eletrônica de Direito Processual - REDP. Volume 15. Janeiro a Junho de 2015 Periódico Semestral da Pós-Graduação Stricto Sensu em Direito Processual da UERJ. Patrono: José Carlos Barbosa Moreira. www.redp.com.br ISSN 1982-7636 PP 74-106 modelo jusnaturalista calcado na busca pela realização da justiça mesmo que em detrimento das normas escritas. Esta concepção tinha um caráter muito mais moral do que propriamente jurídico o que levou ao seu progressivo enfraquecimento.

Em meados do século XIX começa a surgir outro paradigma o juspositivismo, lastreado em um forte racionalismo e que angulariza a importância da norma escrita e positivada sem maiores apelos morais. Segundo:

Como ideologia, o positivismo jurídico se baseia na atribuição de um valor positivo ao direito existente, sem examinar sua correspondência com um direito ideal. Nesse âmbito, o positivismo jurídico é uma ética normativa, cuja característica principal está na coincidência dos critérios para avaliar o caráter justo do direito com os critérios para decidir sobre sua validade. ${ }^{19}$

Também esse paradigma deixa flancos na construção de uma sociedade justa e igualitária. É dizer, o modelo positivista utilizando como farol a lei escrita não atende aos clamores específicos da sociedade e aplica a norma igualitariamente em todas as circunstâncias de modo autômato. Às portas do século XXI há uma nova guinada do Direito evoluindo paulatinamente para um novo paradigma cognominado de póspositivismo.

O pós-positivismo é a designação provisória e genérica de um ideário difuso, no qual se incluem a definição das relações entre valores, princípios e regras, aspectos da chamada nova hermenêutica constitucional, e a teoria dos direitos fundamentais, edificada sobre o fundamento da dignidade humana. A valorização dos princípios, sua incorporação, explícita ou implícita, pelos textos constitucionais e o

\footnotetext{
${ }^{19}$ SCHIAVELLO, Aldo. Positivismo jurídico e relevância metaética. (trad) Soraya Gasparetto Lunardi. In: DIMOULIS, Dimitri; DUARTE, Écio Oto. Teoria do direito neoconstitucional: superação ou reconstrução do positivismo jurídico? São Paulo: Método, 2008. p.64.
} 
Revista Eletrônica de Direito Processual - REDP. Volume 15. Janeiro a Junho de 2015 Periódico Semestral da Pós-Graduação Stricto Sensu em Direito Processual da UERJ. Patrono: José Carlos Barbosa Moreira. www.redp.com.br ISSN 1982-7636 PP 74-106

reconhecimento pela ordem jurídica de sua normatividade fazem parte desse ambiente de reaproximação entre Direito e Ética. ${ }^{20}$

Nesta nova fase, embora haja um respeito elevado às normas positivadas, acresce-se maior valor aos princípios, normas de caráter superior que regem todo o ordenamento jurídico. Inicia-se, assim, o que se poderia denominar de império dos princípios. No Brasil, não estamos imunes a estes novos ares, especialmente a partir da Constituição de 1988, mas não é possível negar que ainda sofremos uma forte tendência ao positivismo jurídico, que regeu nosso ordenamento jurídico ao longo do século XX. Trata-se de um processo cultural a desamarra com o passado ainda recente e a proposição de uma Carta Constitucional que se propõe duradoura, voltada para o futuro, insistindo-se na via do debate acadêmico como um dos caminhos a trilhar.

\subsection{RELAÇÃO ENTRE PRINCÍPIOS E REGRAS}

A concepção hodierna de normas jurídicas baseia-se na bipartição, entre princípios e regras $^{21}$. As regras são todas as normas escritas, são os ordenamentos jurídicos dos diferentes Estados, as Constituições e a legislação infringente. A busca por um conceito de princípios é sobremaneira mais complexa.

Etimologicamente, a palavra princípio remete à ideia de início, começo. Esta conceituação pode ser aproveitada de modo transverso para a compreensão do que sejam os princípios jurídicos. É dizer, os princípios são regramentos que servem para balizar, oferecer fundamentos sólidos a um determinado sistema jurídico. Dá-lhe a consistência para que perdure no tempo, sem embargo de amoldá-lo às novas necessidades que a vida provoca. Na lição de Luis Roberto Barroso ${ }^{22}$ :

\footnotetext{
${ }^{20}$ BARROSO, Luis Roberto; BARCELLOS, Ana Paula de. O começo da história: a nova interpretação constitucional e o papel dos princípios no direito brasileiro. In: BARROSO, Luis Roberto et. al. A nova interpretação constitucional: Ponderação, direitos fundamentais e relações privadas. 2. ed. rev. e atual. Rio de Janeiro: Renovar, 2006. p. 336.

${ }^{21}$ FARIAS, Edilsom Pereira de. Colisão de direitos: a honra, a intimidade, a vida privada e a imagem versus a liberdade de expressão e informação. 3. ed. rev. e atual. Porto Alegre: Sergio Antonio Fabris, 2008.

22 BARROSO, Luis Roberto. Neoconstitucionalismo e constitucionalização do direito: o triunfo tardio do direito constitucional no Brasil. THEMIS, Fortaleza, v.4, n.2, jul./dez. 2006. p. 27.
} 
Revista Eletrônica de Direito Processual - REDP. Volume 15. Janeiro a Junho de 2015 Periódico Semestral da Pós-Graduação Stricto Sensu em Direito Processual da UERJ. Patrono: José Carlos Barbosa Moreira. www.redp.com.br ISSN 1982-7636 PP 74-106

$\mathrm{O}$ reconhecimento de normatividade aos princípios e sua distinção qualitativa em relação às regras é um dos símbolos do pós-positivismo. Princípios não são, como as regras, comandos imediatamente descritivos de condutas específicas, mas sim normas que consagram determinados valores ou indicam fins públicos a serem realizados por diferentes meios.

Assim, para ofertar os fundamentos de um ordenamento, os princípios se valem de influências da Ética, da Filosofia, da Política, da Sociologia e de outras ciências das humanidades. As regras, por seu turno, são normas que interferem na vida dos particulares e do Estado, estabelecendo certas condutas positivas e negativas, com o escopo de organizar a convivência em um dado grupamento social.

Contudo, possuem sua gênese numa atividade humana positiva desempenhada por algum órgão ou ente legislativo. É certo que as regras possuem valor cogente, fazendo-se respeitar pela presença viva de um caráter de obrigatoriedade e impositividade, perceptível desde sempre no seu próprio DNA.

É possível observar, portanto, que os princípios distinguem-se das regras especialmente por possuírem um caráter qualitativo superior ${ }^{23}$. Por via lógica são normas que possuem posição hierárquica superior àquela atribuída às regras, servindo, concomitantemente, para validar a sua existência e de supedâneo para todo o sistema jurídico. Os princípios servem de complemento às regras, em parte, por possuírem um caráter abstrato superior àquele experimentado pelas normas positivadas. Conforme Willis Santiago Guerra Filho ${ }^{24}$ :

[...] os princípios fundamentais, igualmente dotados de validade positiva e de um modo geral estabelecidos na constituição, não se reportam a um fato especifico, que se possa precisar com facilidade a ocorrência, extraindo a conseqüência prevista normativamente. Eles devem ser entendidos como indicadores

\footnotetext{
${ }^{23}$ DIMOULIS, Dimitri; LUNARDI, Soraya Gasparetto. O positivismo jurídico diante da principiologia. In: DIMOULIS, Dimitri; DUARTE, Écio Oto. Teoria do direito neoconstitucional: superação ou reconstrução do positivismo jurídico? São Paulo: Método, 2008.

${ }^{24}$ GUERRA FILHO, Willis Santiago. O processo como referencial teórico para o estudo dos direitos fundamentais. In: NOVELINO, Marcelo. Leituras complementares de direito constitucional: direitos humanos e direitos fundamentais. 3. ed. rev. e atual. Salvador: JusPodivm, 2008. p. 114.
} 
Revista Eletrônica de Direito Processual - REDP. Volume 15. Janeiro a Junho de 2015 Periódico Semestral da Pós-Graduação Stricto Sensu em Direito Processual da UERJ. Patrono: José Carlos Barbosa Moreira. www.redp.com.br ISSN 1982-7636 PP 74-106

de uma opção pelo favorecimento de determinado valor, a ser levada em conta na apreciação jurídica de uma infinidade de fatos e situações possíveis, juntamente com outras tantas opções dessas, outros princípios igualmente adotados, que me determinado caso concreto podem se conflitar uns com os outros, quando já não são mesmo in abstracto, antinômicos entre si.

Além disso, servem para orientar e limitar a atividade do intérprete, coibindo os abusos e, também, para o preenchimento de lacunas na lei. Como acentuado anteriormente, os princípios servem de parâmetro para a validade de todas as regras que compõem um determinado ordenamento jurídico. Neste sentido:

Os princípios jurídicos fundamentais, dotados também de dimensão ética e política, além daquela propriamente positiva, apontam a direção que se deve seguir para tratar de qualquer ocorrência de acordo com o Direito em vigor, caso ele não contenha uma regra que a refira ou que a discipline suficientemente. ${ }^{25}$

Forçoso concluir que os princípios cumprem uma função essencial no ordenamento jurídico, inclusive, complementando de forma juridicamente admissível a eficácia de algumas normas que claudicam diante da ausência de complemento legislativo.

\subsection{PRINCÍPIOS CONSTITUCIONAIS E PROCESSO}

O Direito brasileiro historicamente tem aderido aos princípios admitindo-os como uma forma de aperfeiçoamento da ordem jurídica, posição que se avulta quando se trata da defesa de direitos fundamentais. Este é o caso da longa lista de princípios que compõem o rol do direito processual brasileiro, o que levou à formação de uma

\footnotetext{
${ }^{25}$ GUERRA FILHO, Willis Santiago. Op. cit. p. 114.
} 
Revista Eletrônica de Direito Processual - REDP. Volume 15. Janeiro a Junho de 2015 Periódico Semestral da Pós-Graduação Stricto Sensu em Direito Processual da UERJ. Patrono: José Carlos Barbosa Moreira. www.redp.com.br ISSN 1982-7636 PP 74-106

superestrutura de defesa dos direitos individuais e controle da atuação do Estado-juiz, distribuída topograficamente entre os direitos e garantias fundamentais ${ }^{26}$.

Desta forma, é facilmente identificado no direito pátrio o respeito a princípios como o contraditório e a ampla defesa, o devido processo legal, o juiz natural (e por via de consequência o promotor natural), a publicidade dos atos processuais, a celeridade processual e a duração razoável do processo.

Importante salientar que os princípios que compõem o ordenamento nacional não se encontram em um rol taxativo, na realidade, a listagem é muito complexa e como tal ganham um status de mutabilidade, decorrendo das alterações jurídicas e sociais experimentadas em um dado momento histórico. Dessa forma, a adesão a novos princípios é uma constante e ocorre contínua e interruptamente, não estando limitada por nenhuma atividade legiferante.

Nesse sentido, não é correto apontar a Emenda Constitucional no 45/2004 como marco fundamental para a adoção do princípio da duração razoável do processo no Direito pátrio. Em verdade, tal reforma trouxe a regra constitucional, mas o princípio já era atuante alhures. É certo que a gênese da duração razoável do processo embora relacionada com a celeridade ${ }^{27}$, com o acesso à Justiça e com o devido processo legal também está ligada, como se percebe etimologicamente, ao princípio da razoabilidade. Não se pode medir, no que diz respeito à tempestividade, pela mesma regra o processo que visa à obtenção de alimentos e aquele que visa à declaração de domínio a partir do exercício de posse qualificada. Aliás, melhor exemplo vem da criação dos Juizados Especiais, voltados a compor de forma mais simples e célere causas de menor complexidade fática ou jurídica.

A simples interpretação demonstra que a razoabilidade busca louvar a razão. Neste sentido, razoável é tudo aquilo que seria adequado do ponto de vista do homem médio, ou no caso de uma lide, aquela solução que seria aceitável para a maioria dos interessados, nos limites de um determinado conflito. Em sua gênese o princípio da razoabilidade é uma construção do direito norte-americano com influência do direito inglês (aonde é chamado de princípio da irrazoabilidade) e não se confunde, como

\footnotetext{
${ }^{26}$ OLIVEIRA, André Luis Tabosa de; SANTIAGO, Nestor Eduardo Araruna. A acusação responsável como direito fundamental. In: Encontro Nacional do CONPEDI, XIX, 2010, Fortaleza. Anais do XIX Encontro Nacional do CONPEDI. Florianópolis: FUNJAB, 2010. p. 1.238-1.251.

${ }^{27}$ Importante registrar que não se está adotando a compreensão de que razoável duração do processo seja sinônimo de celeridade processual. Para maior aprofundamento do tema, remete-se o leitor para JOBIM, Marco Félix. O direito à duração razoável do processo: responsabilidade civil do Estado em decorrência da intempestividade processual. 2. ed. Porto Alegre: Livraria do Advogado, 2012.
} 
Revista Eletrônica de Direito Processual - REDP. Volume 15. Janeiro a Junho de 2015 Periódico Semestral da Pós-Graduação Stricto Sensu em Direito Processual da UERJ. Patrono: José Carlos Barbosa Moreira. www.redp.com.br ISSN 1982-7636 PP 74-106

insistem em afirmar alguns, com o princípio da proporcionalidade que foi desenvolvido a partir de reiterada construção jurisprudencial alemã ${ }^{28}$.

Hodiernamente, no direito brasileiro a razoabilidade manifesta-se como uma faceta do devido processo legal, e também, não chega a confundir-se com ele. É na realidade um princípio de caráter genérico que controla a ocorrência e concretização de fatos reprováveis, alçando-se a norma constitucional de primeira grandeza dado seu cunho genérico $^{29}$.

Embora seja possível estabelecer a natureza do instituto da duração razoável do processo, tarefa muito mais árdua será conferir-lhe a necessária aplicabilidade. Indiscutível que como regra constitucional definidora de direitos fundamentais possui eficácia plena e imediata, e que sendo princípio goza da mesma benesse. Ademais escorada nos mesmos argumentos não admite interpretações reducionistas. Neste contexto, resumem Nestor Santiago e Ana Caroline Duarte ${ }^{30}$ :

Pode-se afirmar que a razoável duração do processo está, assim, pela primeira vez, em nosso sistema de direito, elevada de forma explícita ao patamar de imposição jurídico-constitucional, dotada de ampla eficácia e efetividade, pelo que não é dado ao intérprete restringir seu conteúdo.

Contudo, as inquietações emergem com força hercúlea quando se debate a concretização do instituto. É praticamente impossível em estado de sã consciência e considerando a realidade brasileira definir o que seja a razoável duração de um processo, por conta dos interesses envolvidos, em razão das partes e pelos problemas estruturais vivenciados pela Justiça brasileira.

\section{DURAÇÃo RAzó́VEL Do PROCESSO COMO REGRA- PRINCÍPIO}

\footnotetext{
${ }^{28}$ SILVA, Virgílio Afonso da. O proporcional e o razoável. Revista dos Tribunais. n. 798, 2002. p. 23-50.

29 PONTES, Helenilson Cunha. O princípio da proporcionalidade e o direito tributário. São Paulo: Dialética, 2000.

${ }^{30}$ SANTIAGO, Nestor Eduardo Araruna; DUARTE, Ana Caroline Pinho. Op. cit, p. 244.
} 
Revista Eletrônica de Direito Processual - REDP. Volume 15. Janeiro a Junho de 2015 Periódico Semestral da Pós-Graduação Stricto Sensu em Direito Processual da UERJ. Patrono: José Carlos Barbosa Moreira. www.redp.com.br ISSN 1982-7636 PP 74-106

Os princípios, diante de sua condição de superioridade, possuem plena capacidade de influenciar, limitar e adaptar todo o ordenamento jurídico, mesmo porque são comandos que legitimam as regras jurídicas perante o corpo social. Essa condição acaba, muitas vezes, levando o legislador, em especial o constituinte, a criar uma figura heterogênea, que une os dois padrões normativos. São as chamadas normas-princípios ou regras-princípios. De outra banda, é inolvidável que o pensamento kelseniano aponta a Constituição como o ápice da pirâmide representativa de um determinado ordenamento.

As duas ideias são corretas e não conflitantes. Percebe-se, pois, que a regra maior do ordenamento, possui em seu âmago a função precípua de servir como suporte de validade para todas as demais. Neste ponto, já é de se imaginar que ela esteja impregnada de princípios, vez que é função destes servir de sustentáculo ao sistema. É como se operasse uma simbiose entre a regra e o princípio e vice-versa. Dizendo de outra forma, eis aí o entrelaçamento discutido anteriormente, ou seja, se apresentam nitidamente as normas-princípios ou regras-princípios, o que, aliás, é muito corriqueiro na Constituição.

Em síntese, estava criado o clima constitucional propiciador da dicotomia básica princípios/regras (ou princípios/preceitos) e o fato é que, à sua dignidade formal a Constituição adicionou uma dignidade material. É assim recamada de princípios que são valores dignificantes de todo o Direito, é que ela passou a ocupar a centralidade do Ordenamento Jurídico, tanto quantos os princípios passaram a ocupar a centralidade da Constituição. ${ }^{31}$

Desse modo, é perceptível no estudo do direito constitucional e na análise das decisões da Corte Suprema que as regras constitucionais apresentam em seu espírito o escopo inarredável de repristinar alguns princípios jurídicos, muitas vezes confundindose eficazmente com eles.

Esta grandeza principiológica da razoabilidade produz especificidades e ligações íntimas com outros princípios tal qual uma árvore com muitos galhos. Assim, a duração razoável do processo surge desta miscelânea, trazendo límpidos traços de

\footnotetext{
${ }^{31}$ BRITTO, Carlos Ayres. Teoria da constituição. Rio de Janeiro: Forense, 2006. p. 180-181.
} 
Revista Eletrônica de Direito Processual - REDP. Volume 15. Janeiro a Junho de 2015 Periódico Semestral da Pós-Graduação Stricto Sensu em Direito Processual da UERJ. Patrono: José Carlos Barbosa Moreira. www.redp.com.br ISSN 1982-7636 PP 74-106

diversos princípios e materializada formalmente no texto constitucional. Perfeito exemplo do que foi apontado como regras-princípios.

Satisfatória, portanto, será a interpretação que apontar a duração razoável do processo como uma regra-princípio o que, por via lógica, atrairá as características das duas espécies normativas para si. Como primeira consequência, sua cogência agrega valor. Neste quadro, o instituto goza de plena eficácia e não necessita de atuação legislativa positiva para que seja aplicado, podendo ser utilizado incidentalmente no caso concreto a fim de assegurar a defesa do direito do cidadão. Ademais, estão impedidas interpretações restritivas que tosem as benesses conferidas pelo legislador e acabem minorando a força de atuação do princípio.

Considerando estas observações, resta claro que a tradição constitucional brasileira autoriza o aplicador da lei a manejar o instituto com o escopo de assegurar sua eficácia social em um caso concreto mesmo sem que haja uma norma disciplinadora. Esta ação positiva não constituirá em hipótese alguma abuso de poder, mas ao inverso funcionará como interpretação extensiva e buscará a máxima efetividade da Constituição, pilar da Hermenêutica Constitucional brasileira.

Essa construção, entretanto, não afasta a necessidade de construção de normas infraconstitucionais que estabeleçam parâmetros claros para a verificação e controle da duração do processo. Deixar tal tarefa somente sob o jugo único da consciência de um magistrado, como mencionado acima, pode criar um ambiente de insegurança jurídica em decorrência da possível discrepância nos posicionamentos adotados pelos juízes. A constatação é evidente: onde o legislador não atua, o espaço decisional (e, portanto, de poder) - que jamais fica vago - será ocupado pelo julgador.

Nesse contexto, em que pese o reconhecimento da dignidade constitucional do princípio da duração razoável do processo é imperiosa a necessidade da elaboração de normas que disciplinem a matéria com a necessidade clareza e profundidade, com vistas a sua concretude e especificidades em cada caso em que possa ser reclamada sua incidência.

No âmbito do processo civil esta necessidade foi compreendida no novo CPC. Após a análise da perspectiva constitucional, passa-se, agora, ao estudo da duração razoável do processo na esfera infraconstitucional, notadamente, no novel Codex Processual Civil. 
Revista Eletrônica de Direito Processual - REDP. Volume 15. Janeiro a Junho de 2015 Periódico Semestral da Pós-Graduação Stricto Sensu em Direito Processual da UERJ. Patrono: José Carlos Barbosa Moreira. www.redp.com.br ISSN 1982-7636 PP 74-106

\begin{tabular}{lllllllr}
\hline \hline 6 & DURAÇÃO & RAZOÁVEL DO & PROCESSO & NA & ESFERA \\
INFRACONSTITUCIONAL: & PERSPECTIVAS & DO & NOVO & CÓDIGO & DE \\
PROCESSO CIVIL & & & & & &
\end{tabular}

Em que pese a expressa previsão da duração razoável do processo no texto da Constituição republicana, agregando valor como regra-princípio, conforme demonstrado alhures, é certo que a legislação infraconstitucional brasileira não se mantém indiferente à necessidade de dotar as lides de um desfecho alcançado em tempo razoável. Nesse contexto, o novo Código de Processo Civil adotou como uma de suas linhas mestras a defesa do tempo razoável e da celeridade processual, que nem sempre estarão juntas, como sinônimos.

No caput do art. $3^{\circ}$, o Código incorpora o texto constitucional, dispondo que "não se excluirá da apreciação jurisdicional ameaça ou lesão a direito", para, no $\S 4^{\text {o }}$ estabelecer que "as partes têm o direito de obter em prazo razoável a solução integral do mérito, incluída a atividade satisfativa". Esta diretriz nada mais é do que a consolidação da defesa da duração razoável do processo em pleno diploma processual civil. O texto tem caráter simbólico, pois se apresenta logo no início do Código em um Capítulo intitulado: "Das normas fundamentais do processo civil". Sua vinculação com a Constituição é evidente.

Isso significa que todas as disposições que adiante serão apresentadas serão regidas por este ideário de defesa da prestação jurisdicional, o mais plena possível, incluindo sua satisfação (a exemplo, cumprimento da sentença) e qualificada pelo tempo hábil e necessário para o seu alcance. Em outras palavras, claramente o legislador adotou como uma das linhas mestras que deveria nortear a redação e a futura interpretação do novo diploma processual, qual seja, a defesa da duração razoável do processo.

É importante salientar que o novo Código não é o primeiro diploma infraconstitucional a estimular a defesa do tempo adequado na solução de $\operatorname{conflitos}^{32}$,

\footnotetext{
${ }^{32}$ Analisando a legislação processual brasileira é possível apontar como marcos anteriores da defesa da tempestividade processual, com maior ou menor explicitude: a Lei ${ }^{\circ}$ 9.099/95 que criou os Juizados Especiais Cíveis e Criminais; a Lei $\mathrm{n}^{\circ} 10.259 / 01$ que instituiu os Juizados Especiais no âmbito da Justiça Federal; a Lei $\mathrm{n}^{\mathrm{o}} 10.352 / 01$ que modificou as regras do reexame necessário; a Lei $\mathrm{n}^{\mathrm{o}} 10.444 / 02$ que alterou o processo de conhecimento, inserindo em seu conteúdo as eficácias executivas e mandamentais na composição da lide; mais recentemente, as Leis $\mathrm{n}^{\circ}$ 11.232/06 (que modificou o regime de cumprimento das sentenças), 11.276/06 (modificando o regime de nulidades e recursos) e 11.277/06 (possibilitando o julgamento sumário de mérito).
} 
Revista Eletrônica de Direito Processual - REDP. Volume 15. Janeiro a Junho de 2015 Periódico Semestral da Pós-Graduação Stricto Sensu em Direito Processual da UERJ. Patrono: José Carlos Barbosa Moreira. www.redp.com.br ISSN 1982-7636 PP 74-106

contudo, sua importância é sobremaneira aumentada por se tratar do máximo diploma processual civil, em torno do qual gravitam as demais normas processuais em uma espécie de zona de influência.

Nesse sentido, o novo CPC apresenta inúmeras medidas que têm por escopo a defesa de um processo civil tempestivamente mais apto. De destacar, ainda no rol das normas fundamentais, manifestação que merece ser citada e que se refere ao fato que as partes passam a ter como dever a cooperação para garantir um tempo adequado para o deslinde do processo (art. $6^{\circ}$ ). Trata-se de um avanço compartilhar com as partes o dever de buscar a duração razoável do processo, e sua celeridade quando essa característica é essencial ao direito material posto em jogo, visto que o Estado-juiz para entregar a prestação pleiteada o faz também por conta da atuação das próprias partes que podem ou não retardar o processo indevidamente.

Esta medida é reforçada com a explicitação da definição e o estabelecimento de punições mais severas para a litigância de má-fé, no art. 77, incisos II, III e IV, pois certamente defesas destituídas de fundamento, produção de provas inúteis ou desnecessárias e a prática de embaraços ao cumprimento dos comandos judiciais contribuem negativamente para o curso do processo, refletindo-se no seu custo temporal. Somando-se a isso a penalização de tais comportamentos conforme arts. 79 a 81, inclusive no que diz com recursos protelatórios, constrói-se uma rede de comandos legais que, se bem aplicados, caminham no sentido de uma prestação jurisdicional tempestivamente adequada.

Poder-se-ia contrapor que as regras da litigância de má-fé não são nenhuma novidade porque já constam do catálogo do Código Buzaid. Contudo, a mudança fica por conta da influência principiológica, adotada expressamente pelo novo estatuto, no capítulo das normas fundamentais.

O juiz poderá limitar a quantidade de litigantes em um litisconsórcio facultativo nos casos em que a quantidade de indivíduos possa prejudicar a rapidez da solução da lide ou dificultar a defesa ou o cumprimento da sentença (art. 113, $\S 1^{\circ}$ ). Esta disposição, que repete regra anterior, deve ser compreendida conjuntamente com as responsabilidades do magistrado, entre as quais o novo Código inclui expressamente o velar pela duração razoável do processo (art. 139, II); prevenir ou reprimir quaisquer atos meramente protelatórios (art. 139, III) e estimular a prioritariamente a composição 
Revista Eletrônica de Direito Processual - REDP. Volume 15. Janeiro a Junho de 2015 Periódico Semestral da Pós-Graduação Stricto Sensu em Direito Processual da UERJ. Patrono: José Carlos Barbosa Moreira. www.redp.com.br ISSN 1982-7636 PP 74-106

entre as partes (art. 139, V), o que certamente vem ao encontro da tempestividade processual.

Aos serventuários da Justiça caberá o cuidado para que os processos sejam sentenciados na ordem em que foram ajuizadas as ações, para evitar que determinados processos se prolonguem indefinidamente em detrimento de outros (art. 153). Agregase, no particular, a disposição do art. 12, que determina a ordem cronológica a ser seguida nos julgamentos tanto no primeiro grau como nos tribunais, dando-se ampla publicidade a esta lista, para efeitos de consulta pública. Trata-se de uma ingerência legislativa nas administrações dos feitos e dos julgamentos com vistas a evitar que processos - seja por qual razão - fiquem aguardando indefinidamente solução em detrimento de outros.

As medidas referidas até o momento são importantes por pretender estabelecer uma mudança de comportamento em todos os agentes que estão envolvidos com a realidade processual. Este é indubitavelmente um passo importante, contudo, há a necessidade de que as alterações alcancem a parte dogmática do novo Código para consolidar a ideia de defesa da tempestividade processual, espaço que, infelizmente, não se denota significativos avanços. Se o Código foi renovador nas regras gerais, nas regras especiais, nem tanto.

Neste sentido, merece destaque o desejo, contemporâneo ao Código de 1973 e suas reformas, de fortalecimento de sentenças autoexecutáveis sempre que a decisão referir-se ao pagamento de quantia certa. Em outras palavras:

[...] o que se pretende é que o cumprimento da sentença seja feito de forma espontânea pelo executado, a fim de evitar o pagamento da multa prevista no art. 475-J do atual Código de Processo Civil. Não o fazendo, incumbirá ao próprio magistrado, de ofício, adotar as medidas necessárias ao efetivo cumprimento da decisão, inaugurando a fase executiva, independentemente de pedido do credor e sem necessidade de intimação do executado. ${ }^{33}$

\footnotetext{
33 PARENTONI, Leonardo Netto. A celeridade no projeto do novo CPC. Belo Horizonte, Revista da Faculdade de Direito da UFMG, n. 59, jul./ dez. 2011. p. 141.
} 
Revista Eletrônica de Direito Processual - REDP. Volume 15. Janeiro a Junho de 2015 Periódico Semestral da Pós-Graduação Stricto Sensu em Direito Processual da UERJ. Patrono: José Carlos Barbosa Moreira. www.redp.com.br ISSN 1982-7636 PP 74-106

A compreensão sobre a sentença que condena a pagar nos termos assim propostos certamente estimularia a rapidez da satisfação das demandas já julgadas e que estão precedidas da qualificação pela coisa julgada, na medida em que a execução só se dá, como regra geral, depois de vencida a fase recursal.

Em sentido similar, ainda sobre o malfadado art. 475-J do CPC de 1973 (que, registre-se, como adiante se verá, veio recepcionado no novo $\mathrm{CPC}$, tornando atual o debate que à época foi travado):

Remanescia à lei reformista tão-somente criar alguma novidade quanto ao cumprimento espontâneo pelo devedor (e, nesse caso, não se falar em execução ou expropriação), o que até então o texto processual vigente, inclusive nas reformas anteriores, de 1994 a 2002, mantivera-se virgem, mudo e surdo. A lei processual, ressalva feita a algumas situações muito especiais, é o Código do inimigo, é o Código do adverso, é o Código do réu. O adversário não é visto como um cooperador, como um cidadão que também é titular da cidadania, e dos mesmos direitos e deveres individuais e coletivos do art. $5^{\circ}$ da Constituição Federal, sendo as regras elaboradas contra ele, sempre a partir de sua exclusão, de sua não participação. De sorte que não temos a tradição na elaboração de regras que estimulem o pronto cumprimento das ordens judiciais, que reforcem execuções espontâneas, que evitem a litigância pela litigância. ${ }^{34}$

E, mais precisamente sobre o cumprimento espontâneo, prossegue a articulista, defendendo sua incidência a partir da sentença condenatória:

De sorte que pode-se afirmar, sem medo de errar, que mesmo no caso dos processos tramitando junto às instâncias recursais, o prazo de quinze dias para cumprimento espontâneo flui

\footnotetext{
${ }^{34}$ MACEDO, Elaine Harzheim. O cumprimento da sentença e a multa do art. 475-J do CPC sob uma leitura constitucional da Lei ${ }^{\circ}$ 11.232/05, Revista da Ajuris - Associação dos Juízes do Rio Grande do Sul, v. 33, n. 104, Porto Alegre: AJURIS, dezembro de 2006, p. 85.
} 
Revista Eletrônica de Direito Processual - REDP. Volume 15. Janeiro a Junho de 2015 Periódico Semestral da Pós-Graduação Stricto Sensu em Direito Processual da UERJ. Patrono: José Carlos Barbosa Moreira. www.redp.com.br ISSN 1982-7636 PP 74-106

paralelamente ao prazo recursal e do trânsito em julgado, de modo que cabe apenas, assentada a poeira da novidade, cada unidade federativa, guardada as peculiaridades regionais, facilitar ao máximo o recolhimento desses valores, que deverão, pena de incidir a multa de $10 \%$, ocorrer dentro desse período legal, irrelevante se o depósito ocorre no $1^{\mathrm{o}}$ ou no $2^{\mathrm{o}}$ grau, pelo menos até que a questão esteja mais bem regulamentada pelas respectivas Corregedorias de Justiça, ainda que a competência da execução, sem dúvida, seja do primeiro grau. ${ }^{35}$

Contudo, a proposta nasceu envolta em complexidades, passando a ser criticada porque estar-se-ia criando uma hipótese de execução realizada diretamente pelo juiz sem qualquer manifestação do credor ou, ainda, sem primeiro novamente ouvir o réu, réu que já foi condenado em sentença transitada em julgado. Inúmeras discussões perpassam o tema visto que alguns compreendiam que, em tal situação, haveria um aumento desproporcional dos poderes do juiz, enquanto que outros defendiam que primeiro o réu teria que ser intimado para pagamento sem a multa agregada ao valor da condenação (ficando, portanto, em suspenso a execução forçada da sentença trânsita em julgado), sem qualquer ato executório e possibilidade de pagamento sem o acréscimo de multa.

O fato é que tanto uma como outra corrente passou ao largo de uma premissa, a nosso sentir, determinante: a sentença cujo cumprimento se abre está qualificada pela coisa julgada material. De sorte que ser previamente (à execução) intimado para pagar sem multa, tese que se mostrou vencedora, pode ser qualquer coisa, menos pagamento espontâneo, menos pagamento forçado. Mas sem dúvida ofende o instituto da coisa julgada.

O novo Código, no particular, sacramentou na lei a exigência de que após o trânsito em julgado haja prévia intimação para pagamento sem multa, e tão somente depois de decorrido o prazo de quinze dias in albis dar-se início do prazo para o credor promover a execução forçada, conforme arts. $513, \S 2^{\circ}$, e $523, \S 1^{\circ}$. Certamente aqui o novo estatuto renegou a tempestividade processual, criando uma situação no mínimo qualificada pela perplexidade: o credor está munido de uma sentença trânsita em

\footnotetext{
${ }^{35}$ MACEDO, Elaine Harzheim. Op. cit, p. 90.
} 
Revista Eletrônica de Direito Processual - REDP. Volume 15. Janeiro a Junho de 2015 Periódico Semestral da Pós-Graduação Stricto Sensu em Direito Processual da UERJ. Patrono: José Carlos Barbosa Moreira. www.redp.com.br ISSN 1982-7636 PP 74-106

julgado (garantia constitucional da coisa julgada) e nada, nada pode fazer enquanto não fluir o procedimento de intimação e o decurso do prazo para o réu pagar o valor a que foi condenado sem o acréscimo da multa de $10 \%$. De se questionar se para o credor não seria mais vantajoso renunciar a multa de $10 \%$ e desde logo ter a seu favor o $16^{\circ}$ dia isto é, o dia em que a sentença transitou em julgado e que, via de consequência, viabiliza o legítimo imediato cumprimento forçado (= execução de sentença) -, com a expedição de mandado de penhora.

Outra alteração dogmática diz respeito à redução do número de recursos existentes no direito brasileiro, com a eliminação, por exemplo, dos embargos infringentes (art. 994). Ao avanço desta medida, revogando o $3^{\circ}$ grau de jurisdição, contrapõe-se a inovação introduzida pelo art. 942, que prevê, em qualquer hipótese de julgamento não unânime (lembre-se, que os embargos infringentes já vinham reduzidos à hipótese de seu cabimento quando a decisão por maioria reformava a sentença de mérito), portanto irrelevante se a infringência é quanto à extinção do processo em exame de mérito ou se, adentrando no mérito, é para confirmar ou reformar a sentença de primeiro grau, um "prolongamento" do julgamento, com a intervenção de outros julgadores, para tanto convocados. Quando a lei troca seis por meia dúzia, não avançou mais também não recuou. Neste caso, é evidente o recuo do novo estatuto, provocando uma dilação no julgamento e no processamento, se presente a cláusula da tempestividade processual.

$\mathrm{Na}$ mesma toada, ainda que muito tenha se discutido sobre a questão do efeito suspensivo nos recursos ${ }^{36}$, o fato é que o Código de 2015 mantém a regra geral de duplo efeito na apelação (art. 1.012), em nada inovando nas exceções, quando muito no respectivo $\S 4^{\circ}$ abrindo a possibilidade de concessão do efeito suspensivo opus judice, o que de certa forma o art. 558 e seu parágrafo único do CPC de 1973 já admitia. Por outro lado, nos recursos especial e extraordinário, o $\S 5^{\circ}$ do art. 1.029 prevê expressamente a viabilidade de ser concedido o efeito suspensivo mediante provocação do recorrente, o que certamente estimulará o seu manejo, aqui também representando um recuo à legislação que ora se vê sob revogação.

\footnotetext{
36 PAOLINELLI, Camila Mattos. O novo Código de Processo Civil: cogitações sobre os principais aspectos positivos e negativos da estrutura técnico-sistemática do projeto aprovado no Senado. Canoas, Revista Eletrônica Direito e Sociedade. n.1, v. 1, nov. 2013.
} 
Revista Eletrônica de Direito Processual - REDP. Volume 15. Janeiro a Junho de 2015 Periódico Semestral da Pós-Graduação Stricto Sensu em Direito Processual da UERJ. Patrono: José Carlos Barbosa Moreira. www.redp.com.br ISSN 1982-7636 PP 74-106

Ainda que se reconheça que as mudanças pretendidas pelo legislador são importantíssimas para a fixação de um padrão de normas que envolvam a construção de um quadro de defesa da duração razoável do processo tomando como parâmetro de atuação diretrizes legais e não somente o livre arbítrio do julgador, também perceptível que em determinadas áreas, especialmente a recursal, a tempestividade processual cedeu espaço ao excesso de medidas que desvalorizam as instâncias locais e aos juízos que cuidam dos fatos. Privilegiar as instâncias recursais, e, mais ainda, as instâncias recursais superiores, atende a que valores e interesses, talvez seja a pergunta mais importante a ser feita e a mais difícil a ser respondida. Fácil, porém, de concluir, que tais escolhas afastam-se da duração razoável do processo.

\section{À GUISA DE CONCLUSÃo}

A duração razoável do processo fui incluída expressamente no corpo da Constituição de 1988, apenas com a reforma constitucional de 2004, contudo, seu espírito está presente no direito brasileiro há muito tempo, vez que decorre da interpretação de outros princípios clássicos como o acesso à justiça, a efetividade da prestação jurisdicional, a razoabilidade e o devido processo legal.

Dada a sua importância, até mesmo em razão de a lentidão do Judiciário ser uma de suas maiores chagas em tempos em que a vida acontece em uma velocidade incontrolável, é primordial que seja estabelecida de forma inconteste a natureza jurídica do preceito que acolhe a tempestividade do processo, a fim de que se possa afirmar sem erro quais os limites devem ser conferidos a sua aplicabilidade.

Nesse sentido, apresentam-se algumas alternativas claras, alguns compreendendo que o preceito da duração razoável do processo é uma regra constitucional, outros que é um princípio constitucional, contudo, parece mais adequado classificá-lo como regra-princípio, vez que une características das duas categorias e com isto propicia a necessária amplitude interpretativa que o instituto merece.

Mesmo após tal conclusão persiste a necessidade do estabelecimento de regras claras definidoras da duração razoável do processo, o que deve ocorrer no ambiente legislativo infraconstitucional. Tal medida fortalece a segurança jurídica uma vez que diminui a possibilidade dos magistrados decidirem entre o natural conflito que às vezes 
Revista Eletrônica de Direito Processual - REDP. Volume 15. Janeiro a Junho de 2015 Periódico Semestral da Pós-Graduação Stricto Sensu em Direito Processual da UERJ. Patrono: José Carlos Barbosa Moreira. www.redp.com.br ISSN 1982-7636 PP 74-106

se impõe entre a duração razoável do processo e a segurança jurídica na tomada de decisões, elegendo como parâmetros apenas seu livre alvitre.

Nesse sentido, ganha importância - pelo menos teórica - o novo Código de Processo Civil por ter feito uma clara opção, no âmbito das normas fundamentais, pela validação e aplicação da duração razoável do processo, estimulando a tempestividade processual.

Porém, inegável concluir que, em áreas específicas, em especial no cumprimento da sentença e no sistema recursal, o legislador processual se afasta das normas fundamentais que o preâmbulo homenageia e opta por um caminho nitidamente comprometido com o mais amplo e possível debate processual, alimentado pelos reexames e pela ausência de imediata eficácia às decisões recorridas, seguindo a tradição do CPC de 1973 e, por vezes, conferindo espaços maiores à dilação processual.

A escolha é também jurídica, não se nega, mas certamente é o caráter político que mais se acentua. Que diga o jurisdicionado - destinatário último do Código de Processo Civil - sobre o seu mérito.

\section{REFERÊNCIAS BIBLIOGRÁFICAS}

ACRE. TRIBUNAL DE JUSTIÇADO ACRE. Constitucional, Civil e Processual Civil. Indenização por danos morais e patrimoniais. Ação de justificação de reconhecimento de união estável. Demora na prestação jurisdicional. Desídia. Prejuízo da parte autora. Dano configurado. Indenização devida. Apelação Cível no 9. Antônia Norlene Alves X Estado do Acre. Órgão Julgador: Câmara Cível. Relator: Miracele Lopes. Data da publicação: 29/10/2009.

AZEVEDO, Alba Paulo de; SILVA, Maria dos Remédios Fontes. O direito fundamental à duração razoável do processo: abordagem sob uma perspectiva garantista do processo penal. In: Encontro Nacional do CONPEDI, XVIII. 2009, Maringá. Anais do XVIII Encontro Nacional do CONPEDI. [s. l.]: CONPEDI, 2009. p. 4.039-4.059.

BARROSO, Luis Roberto. Neoconstitucionalismo e constitucionalização do direito: o triunfo tardio do direito constitucional no Brasil. THEMIS, Fortaleza, v.4, n.2, jul./dez. 2006. p. 13-101. 
Revista Eletrônica de Direito Processual - REDP. Volume 15. Janeiro a Junho de 2015 Periódico Semestral da Pós-Graduação Stricto Sensu em Direito Processual da UERJ. Patrono: José Carlos Barbosa Moreira. www.redp.com.br ISSN 1982-7636 PP 74-106

. O direito constitucional e a efetividade de suas normas: limites e possibilidades da Constituição brasileira. 6.ed. atual. Rio de Janeiro: Renovar, 2002.

; BARCELLOS, Ana Paula de. O começo da história: a nova interpretação constitucional e o papel dos princípios no direito brasileiro. In: BARROSO, Luis Roberto et al. A nova interpretação constitucional: ponderação, direitos fundamentais e relações privadas. 2. ed. rev. e atual. Rio de Janeiro: Renovar, 2006.

BRITTO, Carlos Ayres. Teoria da constituição. Rio de Janeiro: Forense, 2006.

COUTINHO, Carlos Marden Cabral. Reformas processuais e duração razoável do processo: uma análise à luz do conceito de tempo kairológico. In: Encontro Nacional do CONPEDI, XXI, 2012, Niterói. Anais do XXI Encontro Nacional do CONPEDI. Florianópolis: FUNJAB, 2012. p. 336-356.

DIMOULIS, Dimitri; LUNARDI, Soraya Gasparetto. O positivismo jurídico diante da principiologia. In: DIMOULIS, Dimitri; DUARTE, Écio Oto. Teoria do direito neoconstitucional: superação ou reconstrução do positivismo jurídico? São Paulo: Método, 2008.

DINIZ, Maria Helena. Norma constitucional e seus efeitos. 4. ed. atual. São Paulo: Saraiva, 1998.

EUROPA. Tribunal Europeu dos Direitos do Homem. Caso Martins Castro e Alves Correia de Castro contra Portugal. $n^{\circ}$ Queixa ${ }^{\circ}$ 33729/06. Julgado em 10 de jun de 2008. Disponível em: < http://www.gddc.pt/direitos-humanos/portugaldh/acordaos/traducoes/Acord $\%$ E3o $\% 20$ martins $\% 20 \mathrm{de} \% 20$ castro $\% 20$ tradu $\%$ E7\%E3o\% 20portugu\%EAs\%20-\%20vers\%E3o\%20final1.pdf>. Acesso em: 08 jun. 2015.

FARIAS, Edilsom Pereira de. Colisão de direitos: a honra, a intimidade, a vida privada e a imagem versus a liberdade de expressão e informação. 3. ed. rev. e atual. Porto Alegre: Sergio Antonio Fabris, 2008.

GUERRA FILHO, Willis Santiago. O processo como referencial teórico para o estudo dos direitos fundamentais. In: NOVELINO, Marcelo. Leituras complementares de direito constitucional: direitos humanos e direitos fundamentais. 3. ed. rev. e atual. Salvador: JusPodivm, 2008.

JOBIM, Marco Féliz. O Direito à duração razoável do processo: responsabilidade civil do Estado em decorrência da intempestividade processual. 2. ed. rev. e ampl. Porto Alegre: Livraria do Advogado, 2012. 
Revista Eletrônica de Direito Processual - REDP. Volume 15. Janeiro a Junho de 2015 Periódico Semestral da Pós-Graduação Stricto Sensu em Direito Processual da UERJ. Patrono: José Carlos Barbosa Moreira. www.redp.com.br ISSN 1982-7636 PP 74-106

MACEDO, Elaine Harzheim. O cumprimento da sentença e a multa do art. 475-J do CPC sob uma leitura constitucional da Lei $n^{0} 11.232 / 05$, Revista da Ajuris Associação dos Juízes do Rio Grande do Sul, v. 33, n. 104, Porto Alegre: AJURIS, dezembro de 2006, p. 70-93.

MAFFINI, Rafael Da Cá. Emenda Constitucional n ${ }^{\circ} 45 / 04$ e o conceito de atividade jurídica como requisito de ingresso nas carreiras da magistratura e do Ministério Público. Salvador, Revista Eletrônica sobre a reforma do Estado, n. 15, set./nov. 2008.

OLIVEIRA, André Luis Tabosa de; SANTIAGO, Nestor Eduardo Araruna. A acusação responsável como direito fundamental. In: Encontro Nacional do CONPEDI, XIX, 2010, Fortaleza. Anais do XIX Encontro Nacional do CONPEDI. Florianópolis: FUNJAB, 2010. p. 1.238-1.251.

PAOLINELLI, Camila Mattos. O novo Código de Processo Civil: cogitações sobre os principais aspectos positivos e negativos da estrutura técnico-sistemática do projeto aprovado no Senado. Canoas, Revista Eletrônica Direito e Sociedade. n.1, v. 1, nov. 2013.

PARENTONI, Leonardo Netto. A celeridade no projeto do novo CPC. Belo Horizonte, Revista da Faculdade de Direito da UFMG, n. 59, jul./ dez. 2011. p. 123-166.

PONTES, Helenilson Cunha. $O$ princípio da proporcionalidade e o direito tributário. São Paulo: Dialética, 2000.

SCHIAVELLO, Aldo. Positivismo jurídico e relevância metaética. (trad) Soraya Gasparetto Lunardi. In: DIMOULIS, Dimitri; DUARTE, Écio Oto. Teoria do direito neoconstitucional: superação ou reconstrução do positivismo jurídico? São Paulo: Método, 2008.

SCHMITT, Cristiano Heineck. Direito à razoável duração do processo no Brasil: origens, inobservância e tentativas de concretização. Revista da Faculdade de Direito da UFG, v. 34, n. 1, jan./jun. 2010. p. 40-63.

SANTIAGO, Nestor Eduardo Araruna; DUARTE, Ana Caroline Pinho. Um conceito de duração razoável do processo penal. Revista NEJ-Eletrônica, v. 15, n. 2, maio/ago. 2010. p. 242-256.

SARLET, Ingo Wolfgang. A eficácia dos direitos fundamentais. $7^{\mathrm{a}}$ ed. rev., atul. e ampl., Porto Alegre: Livraria do Advogado, 2007. 
Revista Eletrônica de Direito Processual - REDP. Volume 15. Janeiro a Junho de 2015

Periódico Semestral da Pós-Graduação Stricto Sensu em Direito Processual da UERJ. Patrono: José Carlos Barbosa Moreira. www.redp.com.br ISSN 1982-7636 PP 74-106

SILVA, José Afonso da. Aplicabilidade das normas constitucionais. 5. ed. São Paulo: Malheiros, 2001.

SILVA, Virgílio Afonso da. O proporcional e o razoável. Revista dos Tribunais. $\mathrm{n}$. 798, 2002. p. 23-50. 